\title{
Lessons from Two Years of ePortfolio Implementation in Engineering Tech- nology Courses
}

\section{Dr. Orlando M. Ayala, Old Dominion University}

Dr. Ayala received his BS in Mechanical Engineering with honors (Cum Laude) from Universidad de Oriente (Venezuela) in 1995, MS in Mechanical Engineering in 2001 and PhD in Mechanical Engineering in 2005, both from University of Delaware (USA). Dr. Ayala is currently serving as Assistant Professor of Mechanical Engineering Technology Department, Frank Batten College of Engineering and Technology, Old Dominion University, Norfolk, VA.

Prior to joining ODU in 2013, Dr. Ayala spent three years as a Postdoctoral Researcher at University of Delaware where he expanded his knowledge on simulation of multiphase flows while acquiring skills in high performance parallel computing and scientific computation. Before that, Dr. Ayala hold a faculty position at Universidad de Oriente at Mechanical Engineering Department where he taught and developed graduate and undergraduate courses for a number of subjects such as Fluid Mechanics, Heat Transfer, Thermodynamics, Multiphase Flows, Fluid Mechanics and Hydraulic Machinery, as well as Mechanical Engineering Laboratory courses.

In addition, Dr. Ayala has had the opportunity to work for a number of engineering consulting companies, which have given him an important perspective and exposure to industry. He has been directly involved in at least 20 different engineering projects related to a wide range of industries from petroleum and natural gas industry to brewing and newspaper industries. Dr. Ayala has provided service to professional organizations such as ASME. Since 2008 he has been a member of the Committee of Spanish Translation of ASME Codes and the ASME Subcommittee on Piping and Pipelines in Spanish. Under both memberships the following Codes have been translated: ASME B31.3, ASME B31.8S, ASME B31Q and ASME BPV Sections I.

While maintaining his industrial work active, his research activities have also been very active; Dr. Ayala has published 90 journal and peer-reviewed conference papers. His work has been presented in several international forums in Austria, USA, Venezuela, Japan, France, Mexico, and Argentina. Dr. Ayala has an average citation per year of all his published work of 33.25 .

\section{Dr. Otilia Popescu, Old Dominion University}

Dr. Otilia Popescu received the Engineering Diploma and M.S. degree from the Polytechnic Institute of Bucharest, Romania, and the PhD degree from Rutgers University, all in Electrical and Computer Engineering. Her research interests are in the general areas of communication systems, control theory, and signal processing. She is currently an Assistant Professor in the Department of Engineering Technology, Old Dominion University in Norfolk, Virginia. In the past she has worked for the University of Texas at Dallas, University of Texas at San Antonio, Rutgers University, and Politehnica University of Bucharest. She is a senior member of the IEEE, serves as associate editor for IEEE Communication Letters, and has served in the technical program committee for the IEEE ICC, WCNC, RWW, VTC, GLOBECOM, and CAMAD conferences. 


\title{
Lessons from Two Years ePortfolio Implementation in Engineering Technology Courses
}

\begin{abstract}
In an undergraduate as well as in a graduate academic setting, an ePortfolio is a collection of student work designed to exhibit student's achievements, which often includes student's reflective commentaries. While in academia ePortfolios are used to document the student learning process over time, they have been also well received by employers as work portfolios or showcases. This paper provides detailed explanations of two years of implementation of ePortfolio activities in junior and senior level engineering technology courses. The goal of the paper is to present to the community the best practices learned during the implementation and to provide information on how the ePortfolios can be integrated with other course assignments, enhancing the course outcomes but without raising the burden from the instructor perspective. Class material samples are provided in the Appendix. The best received implementation was observed when: 1) scaffolding of the activity was done along the semester and was aligned with the pre-existing course activities (such as test, HW assignments, etc.), 2) the eP project was made optional for extra credit, 3) detailed instructions were provided, and 4) a website template was provided.
\end{abstract}

\section{Introduction}

Although there is a generalized consensus of the positive outcomes of ePortfolios and ABET has identified portfolios as a way for documenting and assessing student outcomes since 2000, there are still discussions related to storage and administration, time and effort from faculty, assessment, and student participation especially among engineering students (there is evidence that students in vocationally oriented courses are more inclined to participate than in other $\left.\operatorname{areas}^{1}\right)$.

There has been a number of engineering college initiatives addressing all or some of those issues in order to successfully implement ePortfolios college wide. To name a few, Rogers and Williams ${ }^{2}$ presented the results of their implementation in Rose-Hulman Institute of Technology back in 1999. They designed their own ePortfolio system and outlined the stages of such eP development from the initial concept to its testing through a Pilot Project with students at sophomore level. In 2004, when ePortfolios in engineering education was still in its infancy, Knott et al. ${ }^{3}$ described a pilot implementation in Virginia Tech at freshman level with their own developed system. Sargison et al. ${ }^{4}$ in 2005 presented the results of the first trial of introducing some form of ePortfolio to $1^{\text {st }}$ year engineering students as part of an initiative of University of Tasmania. It was used for the students to track their development skills and to help them in their career planning. Unfortunately, in all those cases, they just described the initial implementation and nothing on how they dealt with any issues that might have raised during the implementation.

There has been also some implementation initiative in specific engineering programs. Christy and Fasina ${ }^{5}$ compared the eP implementation in two undergraduate biosystems/biological engineering programs, one from Ohio State University and another one from Auburn University. 
They looked into timing (i.e., how to implement it in a period of time), website platforms, faculty buy-in, and student buy-in. The authors looked at timing by implementing it in a one-time effort in a single course and in a distributed one spread over years and several courses. They noticed that the timing is not a critical aspect on the impact of eP on students. They mentioned that it is more challenging to implement ePortfolio in courses with specific technical content such as Heat Transfer and Fluid Mechanics. As for student buy-in, they noticed that for some students who find ePortfolio uncomfortable, their motivation can be stimulated by the gain in visibility that ePortfolios bring in front of potential employers, and by the increased success rates in job applications. Goodrich et al. ${ }^{6}$ implemented ePortfolios in a 1 st year engineering program to measure student engagement in the class. They measured the engagement by monitoring the number of ePortfolio hits and logins. They also continued monitoring for 3 years to assess student retention. Unfortunately, none of the ePortfolio program implementations described any issues at specific course level and how they overcame them. There have been implementations at engineering graduate programs as well ${ }^{7,8,9}$ but the focus of this paper is at undergraduate level, which has a completely different student population.

Few authors have published in regards with course level ePortfolio implementation. Pakala and Bose ${ }^{10}$ discussed their observation on developing content for ePortfolios using mobile learning strategies in Thermodynamics and Fluid Mechanics courses. The students created videos demonstrating course material summaries and problem-solving techniques using iPads. The authors focused only on the student perception of the implementation. Prather et al. ${ }^{11}$ described their experience implementing ePortfolio in a RF Systems Laboratory, which could be different to an implementation in a theoretical course. Jovanovic et al. ${ }^{12}$ described the ePortfolio initiative at Old Dominion University and the first eP implementation in a senior course on Computer Integrated Manufacturing in summer 2015. With a single semester implementation, they suggested to introduce ePortfolio early in the semester, provide examples, and links to learn about website tools.

In the last two years, the authors of this paper introduced ePortfolio activities in Engineering Technology Courses at junior and senior level at Old Dominion University (ODU). The initial idea of the implementation was to provide students with a tool to better market themselves in front of potential employers, providing a way to display their academic projects and industrial expertise. However, during the ePortfolio implementation, the tool became an extraordinary rich learning experience for the students. Junior and senior level courses were considered for this study, and ePortfolio implementations at this level have been less documented in the literature. In the particular case discussed here, there is also a wide diversity among students participating in the study, including traditional students, students in different age groups (with a large group of students returning to school after a long break period), full-time workers, active military students, veterans, students of underrepresented groups, and transfer students from community colleges. This diverse student body is atypical in most of ePortfolio implementation studies.

The main objective of this paper is to share the lessons learned during the two years period of the ePortfolio implementation. 


\section{Why implementing ePortfolios?}

The 3 credits courses chosen for the implementation were Fluid Mechanics, Thermal Applications, Heat Transfer, and Air Conditioning Systems. All of them are part of the engineering technology program at Old Dominion University (ODU). As part of the performance evaluation in each course, the course includes a final engineering project where the students must demonstrate their ability to use the concepts learned in the class for solving real world engineering problems. Over the years the feedback the faculty has received from former students regarding the projects was excellent. The latest email from a former student regarding the projects reads as follow:

"I wanted to reach out to you and give you a sort of update from a former student. I accepted last Tuesday, and will be starting this coming Monday, an offer from The Bell Company as a Project Engineer. I'll be moving to Charleston, SC to finish up a \$24M contract they have with the Naval Weapons Station there, upgrading their Nuclear Power Training Unit.

I definitely have to say, and feel free to blast this to all of your current students, the projects you had us complete in all of your courses helped immensely with not just getting the job but feeling comfortable walking into it next week. The HVAC and Heat Transfer courses were incredibly beneficial, as well, since I'll be overseeing massive HVAC installs. Being able to walk into an interview and recite numerous projects you did relating to real world situations showed not just the knowledge, but the determination it took to complete such hefty assignments.

So, a big thank you to you for instilling both knowledge and commitment during your courses. I hope all is going well there and I definitely intent on keeping in touch."

The student's message shows that the students find the projects to be extremely beneficial in pursuing a job. It gives them confidence. Since the class projects have been such a success, and since these projects are the best artifacts to present students' expertise and capabilities, it is natural to consider them as first choice for an ePortfolio showcase. This is where the idea started, to provide students with a tool to better market themselves in front of potential employers, providing a way to display their projects and industrial expertise.

\section{ODU eP3 Workshops}

As part of its 2015-2019 Strategic Plan, Old Dominion University fully supports the development and implementation of ePortfolios. The inclusion in the Strategic Plan came after few years of exploring such implementation with encouraging but at the same time limited results. All the programs and individual ODU faculty who have adopted ePortfolio have shown success, but there are still only few programs and professors who have done it. In an effort to scale up the ePortfolio initiative at ODU, the Center for High Impact Practices has been offering a series of 3-day workshops for the instructors interested in adopting ePortfolios in their courses. The participants are exposed to strategies to promote active and integrative learning, and they are also helped to plan on how they will incorporate ePortfolios within a course in a following semester. The "eP3: Praxis, Process, \& Production ePortfolio" workshop was first offered in May 2015 when the authors participated. Following the success of the workshop (they had a sustained average participation of 20 to 25 participants), the Center decided to developed a 
follow-up workshop: "Beyond eP3". In there, the participants were guided to develop a website template in Wordpress to include later in a course. The authors enrolled in the first cohort of this follow-up workshop in December 2016. The tools learned in both workshops were utilized to introduce the ePortfolio in the courses mentioned above, and the learning experience is presented in this paper.

\section{eP Implementation over five semesters}

The first ePortfolio was implemented in Fall 2015. The associated activities were required in the course and were part of the grading criteria:
a. 1 st test (including HW) $20 \%$
b. 2nd test (including HW) $20 \%$
c. 3rd test (including HW) $20 \%$
d. Course project $30 \%$
e. Peer review assignment $5 \%$
f. ePortfolio $5 \%$

The ePortfolio activities consisted in 4 main activities: 1) Setup google drive folders, 2) Upload artifacts to folders as they were produced, 3) Develop a showcase ePortfolio with links to archived artifacts, and 4) Complete ePortfolio reflective assignment. These general activities were kept unchanged throughout the whole implementation in the 2 years period, but their subactivities were adjusted from one semester to the next one. The reflective assignment was part of the requirements of the $\mathrm{eP} 3$ workshop and turned out to be one of the highlights of the eP implementation. All the activities were initially scaffolded with small sub-activities throughout the semester as follows:

\begin{tabular}{|c|c|c|}
\hline Due Date & Activities & \\
\hline $\begin{array}{l}\text { Tuesday } 09 / 08 / 15 \\
\text { before class }\end{array}$ & $\begin{array}{l}\text { - Google drive set up } \\
\text { - Upload artifacts }\end{array}$ & $20 \%$ \\
\hline $\begin{array}{l}\text { Tuesday } 09 / 29 / 15 \\
\text { before class }\end{array}$ & - Upload artifacts & $10 \%$ \\
\hline $\begin{array}{l}\text { Tuesday 10/20/15 } \\
\text { before class }\end{array}$ & $\begin{array}{l}\text { - ePortfolio platform set up } \\
\text { - Upload artifacts }\end{array}$ & $20 \%$ \\
\hline $\begin{array}{l}\text { Tuesday } 11 / 10 / 15 \\
\text { before class }\end{array}$ & $\begin{array}{l}\text { - Upload artifacts } \\
\text { - Update showcase eP }\end{array}$ & $10 \%$ \\
\hline $\begin{array}{l}\text { Thursday } 12 / 10 / 15 \\
\text { before noon }\end{array}$ & $\begin{array}{l}\text { - Reflections } \\
\text { - Final showcase eP }\end{array}$ & $40 \%$ \\
\hline
\end{tabular}


The first implementation was not well received by the students. Many of them complained for the amount of work in exchange for only few points in their final grade. The majority of the students did not complete the whole assignment and opted out from completing the website. However, they worked on their course reflections. The feedback from the students pointed out that some of the instructions for the eP activities could be seen as confusing or not detailed enough to be able to complete them. In addition, the students struggled keeping up with all the activities in the class (such as ePortfolio, Peer Review, Course Project, and Flipped Classroom), which overlapped over several weeks in the semester.

In the following semesters the instructor modified the implementation strategy several times. As shown in Table 1, the instructor made changes in the grading criteria, the scaffolding of the eP activities, and the activity instructions. After all the changes, the latest grading criteria became:
a. 1 st test (including $\mathrm{HW}$ )
$22 \%$
b. 2nd test (including HW)
$22 \%$
c. 3rd test (including HW) 22\%
d. Semester-long Course project $34 \%$
e. ePortfolio
OPTIONAL

The course project became a semester-long project and the peer-review activity was integrated into the project. Currently, the 4 main eP activities are scaffolded with 4 main deliverables that were aligned with tests and project deliveries as follows:

\begin{tabular}{|c|c|c|}
\hline Due Dates & Activities & Additional Points \\
\hline $\begin{array}{c}\mathrm{T} \\
02 / 13 \\
(7 \text { days after test }) \\
\end{array}$ & $\begin{array}{c}1^{\text {st }} \text { test reflection, Google drive } \\
\text { and website set up, and eP } \\
\text { update (upload artifacts, i.e, } \\
\text { tests, HWs) }\end{array}$ & 4 points towards $1^{\text {st }}$ test \\
\hline $\begin{array}{c}\mathrm{T} \\
03 / 20 \\
(2 \text { days after test }) \\
\end{array}$ & $\begin{array}{l}2^{\text {nd }} \text { test reflection, and } \mathrm{eP} \\
\text { update (upload artifacts, i.e, } \\
\text { tests, HWs) }\end{array}$ & 4 points towards $2^{\text {nd }}$ test \\
\hline $\begin{array}{c}\mathrm{R} \\
04 / 12 \\
\text { (2 days after test) } \\
\end{array}$ & $\begin{array}{c}3^{\text {rd }} \text { test reflection, and eP } \\
\text { update (upload artifacts, i.e, } \\
\text { tests, HWs) }\end{array}$ & 4 points towards $3^{\text {rd }}$ test \\
\hline $\begin{array}{c}\text { Sunday } \\
04 / 29 \\
\text { (2 days after project) } \\
\end{array}$ & $\begin{array}{l}\text { eP Reflective letter \& final eP } \\
\text { showcase }\end{array}$ & 3 points towards final grade \\
\hline
\end{tabular}


Table 1 . Summary of the changes along the 2 years eP implementation.

\begin{tabular}{|c|c|c|c|}
\hline SEMESTER & GRADING & ACTIVITIES & MAIN COMMENTS \\
\hline Fall 2015 & $\begin{array}{l}5 \% \text { of final } \\
\text { grade }\end{array}$ & $\begin{array}{l}5 \text { deliverables } \\
\text { turned in } \\
\text { approx every } 3 \\
\text { weeks }\end{array}$ & $\begin{array}{l}\text { a. Students complained workload } \\
\text { b. Instructions could be confusing } \\
\text { c. All of them worked on reflections but only two or } \\
\text { three meaningful websites. } \\
\text { TO DO: } \\
\text { Scaffold further the activities, revise instructions } \\
\text { (especially for reflections), and make the eP project } \\
\text { optional for extra credits. }\end{array}$ \\
\hline Spring 2016 & $\begin{array}{l}\text { Optional } \\
\text { (extra points) }\end{array}$ & $\begin{array}{l}5 \text { deliverables } \\
\text { (with more } \\
\text { small } \\
\text { activities) } \\
\text { turned in } \\
\text { approx every } 3 \\
\text { weeks }\end{array}$ & $\begin{array}{l}\text { a. Students complained again workload } \\
\text { b. Instructions for website incomplete } \\
\text { c. No meaningful websites but worthwhile } \\
\text { reflections. } \\
\text { TO DO: } \\
\text { Scaffold the activities aligning them to pre-existing } \\
\text { course activities, and further revise instructions } \\
\text { (especially for reflections) providing samples. } \\
\text { KEEP: } \\
\text { eP project optional for extra credits. }\end{array}$ \\
\hline Fall 2016 & $\begin{array}{l}\text { Optional } \\
\text { (extra points) }\end{array}$ & $\begin{array}{l}4 \text { deliverables } \\
\text { that follow } \\
\text { right after tests } \\
\text { and project }\end{array}$ & $\begin{array}{l}\text { a. No more complains. } \\
\text { b. Students got interested in website development, } \\
\text { seeked for help. } \\
\text { TO DO: } \\
\text { Further revise all instructions (with samples), and } \\
\text { provide a website template in Wordpress (after } \\
\text { "ODU Beyond eP3"). } \\
\text { KEEP: } \\
\text { Activities and eP project optional for extra credits. }\end{array}$ \\
\hline Spring 2017 & $\begin{array}{l}\text { Optional } \\
\text { (extra points) }\end{array}$ & $\begin{array}{l}4 \text { deliverables } \\
\text { that follow } \\
\text { right after tests } \\
\text { and project }\end{array}$ & $\begin{array}{l}\text { a. Again, no complains. } \\
\text { b. Students created nice websites with significant } \\
\text { reflections. } \\
\text { TO DO: } \\
\text { Final touches to instructions. } \\
\text { KEEP: } \\
\text { Activities, eP project optional for extra credits, and } \\
\text { website template. }\end{array}$ \\
\hline Fall 2017 & $\begin{array}{l}\text { Optional } \\
\text { (extra points) }\end{array}$ & $\begin{array}{l}4 \text { deliverables } \\
\text { that follow } \\
\text { right after tests } \\
\text { and project }\end{array}$ & $\begin{array}{l}\text { Same observations as in Spring 2017. Repeat eP } \\
\text { project as it is for next semester Spring } 2018 .\end{array}$ \\
\hline
\end{tabular}


For the 1st deliverable extra time was offered to complete the sub-activities as they involved some reading and extra work that is not later required. The total additional points the students could earn if completing the sub-activities have been lowered every semester. The instructor has noticed no effect in student participation in the optional activity due to those changes. Table 2 shows the student participation in the eP activities. The participation was 100\% in Fall 2015 because the activity was required, soon after it became optional the participation dropped and has gone up and down without clear pattern but with an overall tendency to increase. The increase tendency proves the success of the adjustments in the implementation as shown in table 1.

Table 2. Summary of student participation in the eP activities.

\begin{tabular}{|c|c|}
\hline Fall 2015 & $100.0 \%$ \\
\hline Spring 2016 & $25.0 \%$ \\
\hline Fall 2016 & $46.0 \%$ \\
\hline Spring 2017 & $29.7 \%$ \\
\hline Fall 2017 & $50.9 \%$ \\
\hline
\end{tabular}

All the changes are reflected in the latest version of the ePortfolio assignment included in the Appendix. The students were not required to read the assignment all at once, they read it as required by the sub-activities. One of the most important changes was the alignment of the subactivities with pre-existing course activities (tests). The students were asked to reflect on their test work. They were asked to: 1) explain how (and why) their work demonstrate their knowledge in the different course learning objectives covered in the test, 2) compare their test against the available solutions (soon after the test submission deadline, the solution to the test was available) and statement of the mistakes they made and what they will do next time to avoid making same mistakes, 3) grade themselves following provided rubrics, and 4) discuss their learning experience and where they could apply the new learned knowledge. They were also asked to upload to the Google drive the test and the test reflection to then link them in their website.

As mentioned in table 1, in Spring 2017 the instructor provided a website template using Wordpress, which is available for free to all ODU students. Figure 1 shows such template. The template was prepared during the "ODU Beyond eP3" workshop the instructors attended in December 2016. The website template was well received by all the students who participated in the eP activities. The students were encouraged to make the website their own. Some students preferred to use other website providers. 


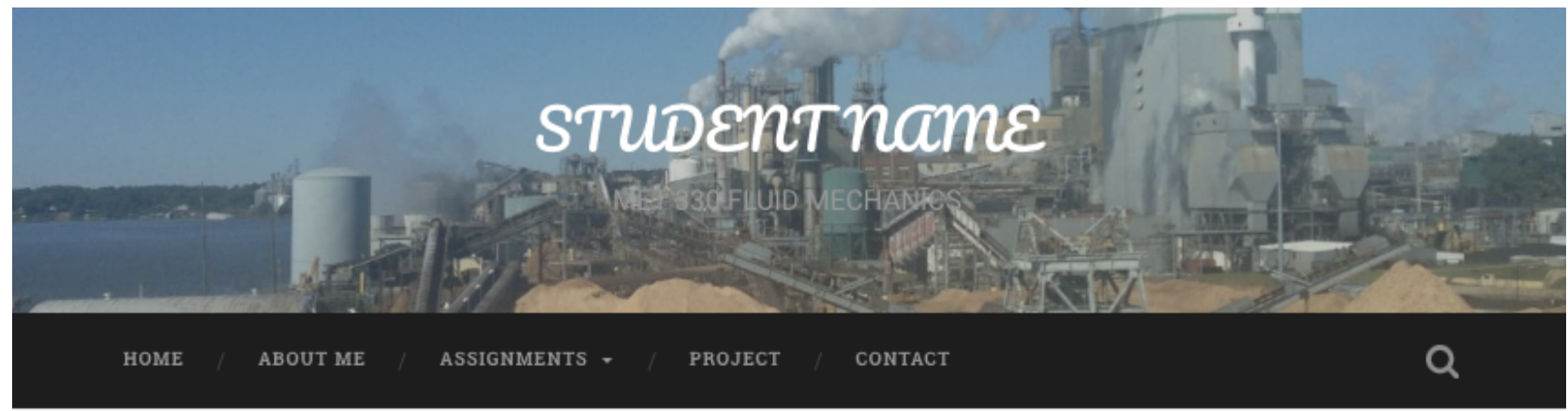

\section{Home}

Describe what you expect to learn in this class. This is to introduce

the course web page.

Also, tell the visitor who read what they will find here.

These whole page will change at the end of the semester when you will be given a new set of instructions on what to write here.

However, do not change anything you write the first time here.

Delete these instructions when adding your material.

Figure 1. Website template provided to the students. Not all of them use it. Some of them were more comfortable with other website providers.

\section{ePortfolio examples}

Figures 2 is a snapshot of one of the most outstanding student ePortfolios. The student took advantage of the opportunity and added material from other classes in his ePortfolio. Figure 3 is the snapshot of an ePortfolio prepared by a former student who already graduated and was 
seeking for a new job. He contacted the instructor to get the instructions he got in class to follow them again to create his new ePortfolio. This student used all his archived material from the instructor courses.

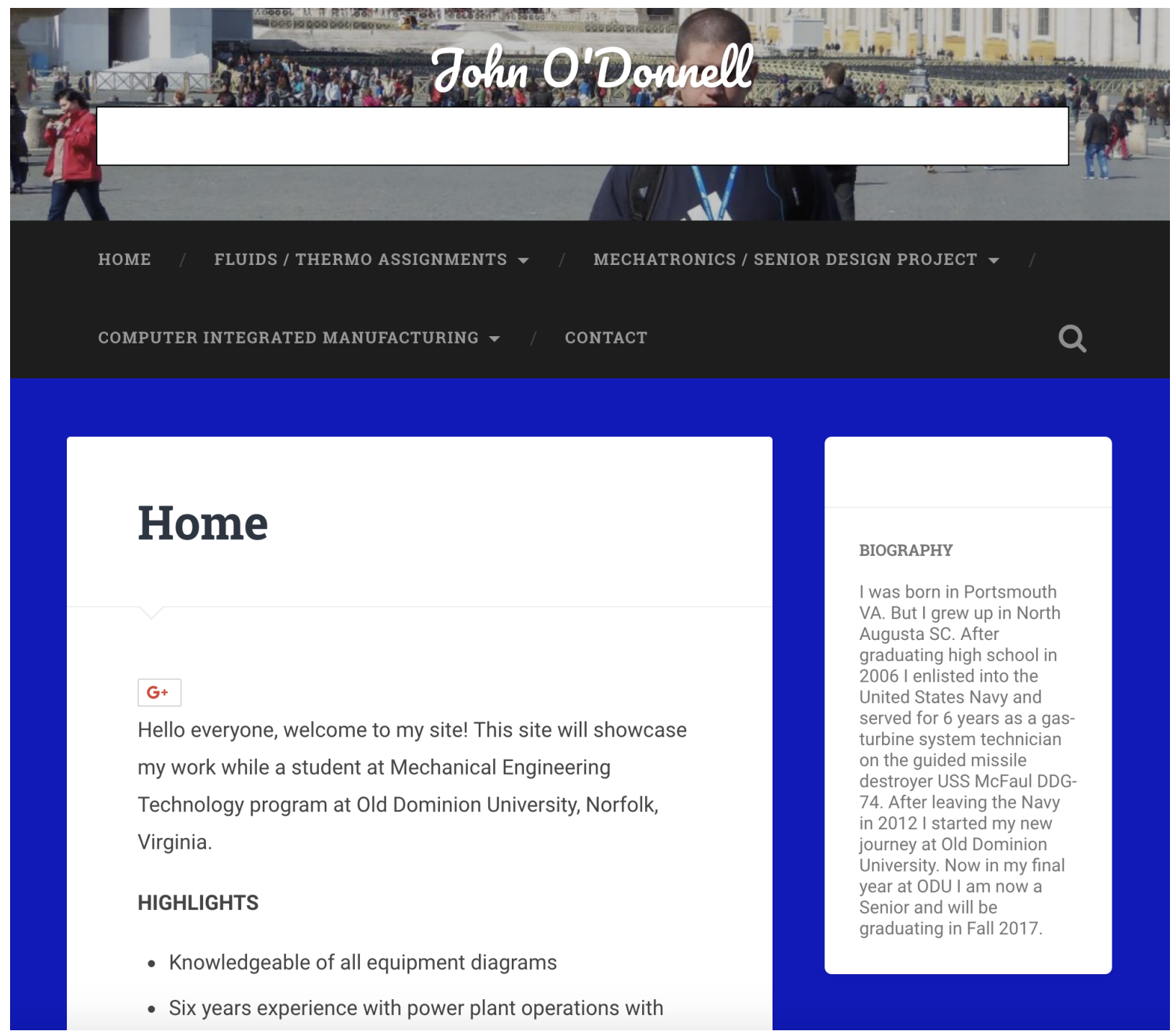

Figure 2. Website of a former student who took the instructor class. The student also incorporated material from other of his classes. 


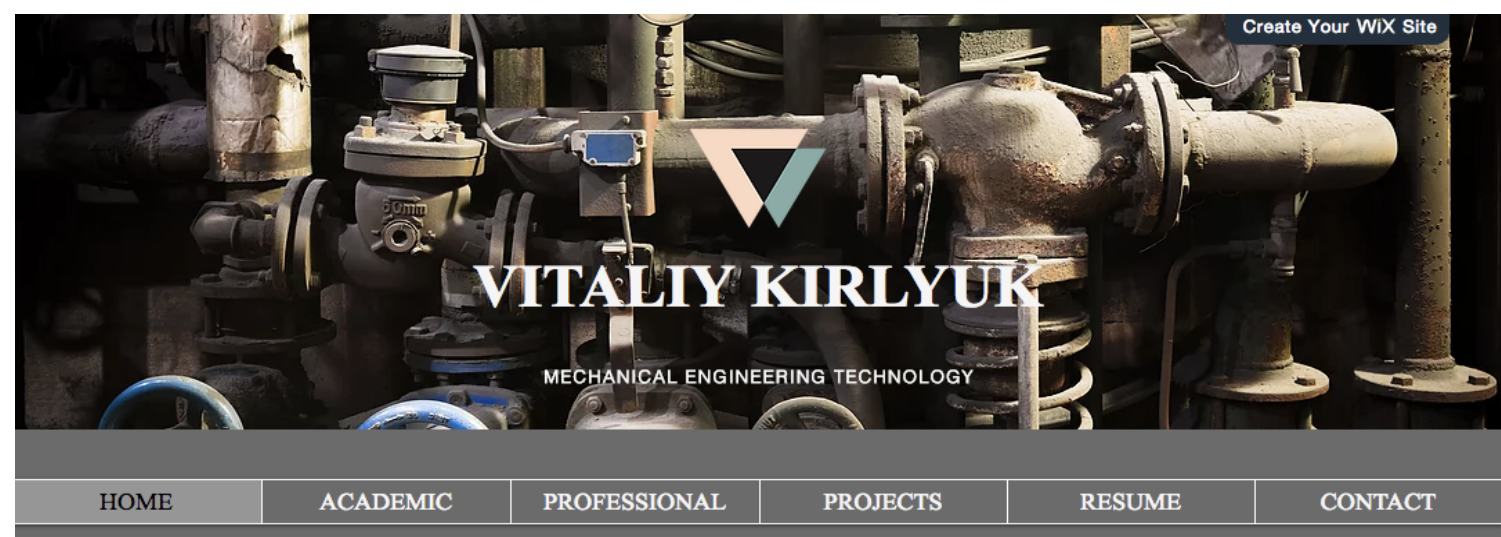

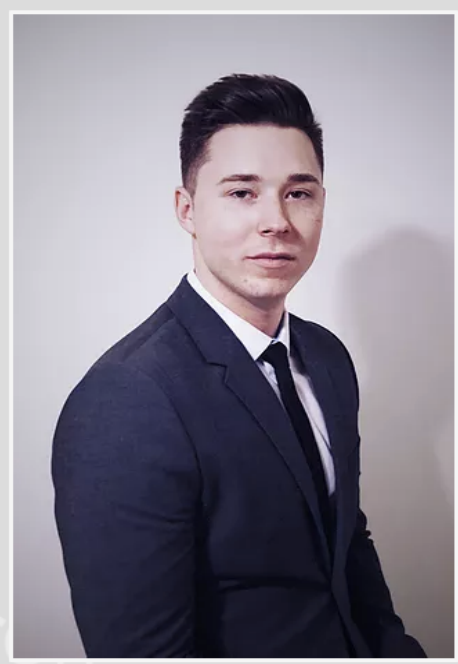

Name: Vitaliy Kirilyuk

Age: 23

Nationality: 2nd Gen. Ukrainian (American Citizen)

Occupation: Product Technician

\section{VITALIY KIRILYUK}

My name is Vitaliy Kirilyuk, I am a graduate from Old Dominion University with a Bachelor of Science in Mechanical Engineering Technology. I am currently employed as a Product Technician - Project Manager in Training with Clear Flow, CP\&P. Please visit the Professional page for more information and examples of my work.

My education started at Blue Ridge Community College, where I pursued my Associate of Science in Specialized Sciences transfer degree. My second year into the program, I was hired at Clear Flow, CP\&P as a CAD Technician. I saw this as an opportunity to get my foot in the door and start building my professional experience.

Working and schooling was not easy but the hard work and dedication paid off. After a couple months of working at CP\&P, I was informed that I could be the next Project Manager in the Clear Flow division and that only fueled my desire to further advance my qualifications.

Following my education at Blue Ridge, I was accepted into Old Dominion University and pursued their B.S.M.E.T. program which allowed me to continue working and schooling.

Now I am a B.S.M.E.T. graduate with almost 4 years of work experience in a professional environment. I have developed many essential skills that can only be acquired by working in the field. Those skills accompanied by my education, have given me the ability to be an exceptionally successful candidate for many positions related to my field of study.

Figure 3. Website of a former student seeking for another job. The student used all the archived material during the instructor courses.

Another important part of the ePortfolio activities is the final reflections. Not only the students were required to reflect on their work on each of the tests, but at the end of the semester, they also had to reflect on their learning experience during the whole course. The instructions for all reflection activities are shown in the ePortfolio assignment (see Appendix). Here it is one of the final reflective letters the instructor has reviewed: 
"Throughout all of my years of schooling, this class in particular will always stick with me. Prior to taking this course I was not very familiar with the concepts of fluid mechanics or where to even begin. The basics of this class started with Bernoulli's equation which was the basis of what this class was all about. Upon learning this equation, it unlocked how to find the basic energy principles of flowing fluids. After deciding to go with the semester long project, I knew I was in for a handful. By deciding to go with the semester long project it really made me have to use the knowledge learned in the class and to think outside of the box. All of the information that I have learned in this class is shown in the final project. I thought it was very interesting to see how our initial designs went on to take an effect throughout the whole project. I had never been tasked with doing anything of this caliber which is going to be hugely beneficial to me because this has given me a slight taste of real engineering. I can honestly say that completing this project has left me with the most accomplished feeling I've ever felt. I believe that by choosing to do this it will be hugely beneficial to my engineering career because it was an actual engineering problem that I had to solve. In the future I believe that this information will come in handy because as an engineer, understanding fluids and how they work in systems can be important in everyday life because fluids are all around us. In the end, this was not an easy class, it requires a lot of work and dedication if doing the semester long project. With that being said, I would not go back on my decision to do the project, all of the hard work and hours that were put into this class and project have given me the most accomplished feeling I have ever felt. Upon checking my final grade on the project, it was one of the happiest/most accomplished feelings I have ever felt. Thank you Professor Ayala!"

\section{Conclusions}

This paper presents the instructor experiences during the implementation of ePortfolios in junior to senior level courses in the Engineering Technology Program at ODU. The main takeaway is that the ePortfolio activities should be aligned with the regular class activities such as tests, HW assignments, and projects. It is the instructor viewpoint that the ePortfolio activities should considered for extra credit since they help the students to improve their grades while they learn to reflect regularly on their learning. The students need help with this new type of assignment (specially the many of them who are reluctant to the idea), thus detailed instructions and a website template help immensely. The overall production of student reflections was a rewarding experience for the instructor since a great deal was learned about the student's perspectives on their learning process and what they were able to accomplish in the class. Former students have reached out to the instructor to mention about the benefits of the ePortfolio too. The latest comment was:

"I start working at AMF Jan 3rd...as a manufacturing engineer intern... used our eportfolio, it's a great tool wanted to thank you for encouraging its creation... Have a great Xmas."

\section{References}

1. Sargison J.E., Tatham P., and Apsitis I. (2005). Introducing students to ePortfolio to record generic attributes. 2005 ASEE/AaeE $4^{\text {th }}$ Global Colloquium on Engineering Education, Australian Association for Engineering Education. 
2. Rogers, G., and Williams J.M. (1999). Asynchronous assessment: Using electronic portfolios to assess student outcomes. $106^{\text {th }}$ ASEE Annual Conference \& Exposition, June 20-23 1999 , Charlotte, NC.

3. Knott T.W., Lohani V.K., Griffin O.H., Loganathan G.V., Adel G.T., and Wildman T.M. (2004). Bridges for Engineering Education: Exploring ePortfolios in Engineering Education at Virginia Tech. $111^{\text {th }}$ ASEE Annual Conference \& Exposition, June 20-23 2004, Salt Lake City, UT.

4. Sargison J.E., Tatham P., and Apsitis I. (2005). Introducing students to ePortfolio to record generic attributes. 2005 ASEE/AaeE $4^{\text {th }}$ Global Colloquium on Engineering Education, Australian Association for Engineering Education.

5. Christy A.D., and Fasina O. (2017). Student ePortfolios for Undergraduate Professional Development: A Comparison of Two Programs. $124^{\text {th }}$ ASEE Annual Conference \& Exposition, June 25-28 2017, Columbus, OH.

6. Goodrich V.E., Marques de Aguiar E., Ambrose G.A., and McWilliams L.H. (2014). Integration of ePortfolios in a First Year Engineering Course for Measuring Student Engagement. $121^{\text {st }}$ ASEE Annual Conference \& Exposition, June 15-18 2014, Indianapolis, IN.

7. McNair L.D., and Garrison W. (2012). Portfolios to Professoriate: Helping Students Integrate Professional Identities through ePortfolios. $119^{\text {th }}$ ASEE Annual Conference $\&$ Exposition, June 10-13 2012, San Antonio, TX.

8. Kajfez R.L., Mohammadi-Aragh M.J., Brown P.R., Mann K.A., Carrico C.A., Cross K.J., Janeski J.A., and McNair L.D. (2013). Assessing Graduate Engineering Programs with ePortfolios: A Comprehensive Design Process. Advances in Engineering Education.

9. Mohammadi-Aragh M.J., and McNair L.D. (2013). Graduate Engineering Student Perceptions of ePortfolio and the Role of Department Culture. 120 $0^{\text {th }}$ ASEE Annual Conference \& Exposition, June 23-26 2013, Atlanta, GA.

10. Pakala K., and Bose D. (2015). Use of mobile learning strategies and devices for e-portfolio content creation in an engineering Thermodynamics and Fluid Mechanics classes: Student perceptions. $122^{\text {nd }}$ ASEE Annual Conference \& Exposition, June 14-17 2015, Seattle, WA.

11. Prather C., Harrell H.K, Bartlett L.E., and Wentworth S.M. (2016). Enhanced Radio Lab Experience Using ePortfolios. 123 ${ }^{\text {rd }}$ ASEE Annual Conference \& Exposition, June 26-29 2016, New Orleans, LA.

12. Jovanovic V., Mize M., Rodrigo R., and Verma A. (2016). Use of ePortfolio as Integrated Learning Strategy in Computer Integrated Manufacturing Online Course. $123^{\text {rd }}$ ASEE Annual Conference \& Exposition, June 26-29 2016, New Orleans, LA. 


\section{Appendix}

\section{$\underline{\text { ePortfolio Assignment }}$}

You will develop an ePortfolio that will contain all the material (artifacts) you produce on all activities you worked on during the class (tests, HW, peer-review feedback, project, etc.), and a reflective letter.

The reason I do this is because some of my former students have told me that a key factor in their hiring process has been mentioning the experience they had with the project. There is no better way to show to the world your work and what you are capable of doing than through an ePortfolio. Be mindful of the quality of what you put there as it is going to be seen by potential employers. This ePortfolio is also a good opportunity to include any information relevant to your learning process throughout your whole academic formation (i.e., other classes, etc.). Look at this article where the importance of $\mathrm{eP}$ is discussed:

\section{https://nextcity.org/daily/entry/eportfolio-job-seekers-show-off-their-skills}

Also look at the ePortfolio one former student of mine put together to get a job:

\section{https://vkirilyuk1.wixsite.com/eportfolio}

There are few main short activities involving the ePortfolio. All of them are due right after each of the tests and project. The activities are:

1) Set up Google drive folders.

2) Upload to the folders all artifacts (HW assignments, tests, test reflections, etc.)

3) Write test reflections.

4) Develop a showcase ePortfolio using a provided template to show all artifacts in a web page.

5) Write a final course reflection (ePortfolio reflective letter).

\section{$\underline{\text { SET UP GOOGLE DRIVE FOLDERS }}$}

1) Using your ID and password, log in to your Google Drive account/

2) Log in to Drive, and click "Create" or "New," and select "Folder."

3) Using your last and first names, name the folder as "Last First ePortfolio"

4) Double click on the Folder

5) At the top of the frame, you can see the title of your folder; hover your mouse next to it, and a triangle appears. Click the triangle. 
6) Select "Share"

7) Under "People," type xxxx@odu.edu (make sure you spelled it right!). Make sure you grant me "edit" rights.

8) Click Done

9) Hover your mouse again next to "ePortfolio" folder, and a triangle appears. Click the triangle.

10) Select "New Folder"

11) Name the new folder "Academic Material"

12) Repeat steps 10 and 11 as many times as needed until you get at least the following folders for:
a. Academic Material
b. Co-curricular \& Leadership Activities
c. Extra-curricular Activities
d. Professional \& Civic Activities
e. Awards \& Scholarships

13) Go to your "Academic Material" folder.

14) At the top of the frame, you can see the title of the folder; hover your mouse next to it, and a triangle appears. Click the triangle.

15) Select "New Folder"

16) Name the new folder "Spring 2018"

17) Double click on that folder.

18) Following similar steps as above, create the folder "MET 330".

19) Double click on that new "MET 330" folder.

20) Create the following folders:
a. Syllabus
b. HWs
c. Tests 

d. Project
e. Reflections

NOTE: Feel free to add as many folders as you see fit to your case.

\section{UPLOAD ARTIFACTS}

1) Double click on top of the folders until you get to the folder where you want to upload the artifact

2) Click "New" and select "File Upload" or hit the upload button next to "Create."

3) Browse and select the artifact. Upload it.

NOTE: A piece of advice is to get used to upload all your artifacts as you produce them.

\section{DEVELOP A SHOWCASE EPORTFOLIO}

I developed a web page template using Wordpress for you to modify. Please visit it in:

https://sites.wp.odu.edu/met330template/

You will personalize and update the web page after every test but I encourage you to do it even before, at any time.

Please watch first the videos located under the ePortfolio tab in Blackboard.

You will also find useful information in the following links:

1) Logging into ODU's System, see:

https://docs.google.com/document/d/1Qb-BFh1sxyJMJA7mLL8F$\underline{\text { r2uPcSrRW11BeQvL00J5aQ/edit }}$

2) Using ODU Templates, see:

https://docs.google.com/document/d/1atp2Ltg6W58goclTcHmtw7gq3NNVtgoCdKtTfv4j-pI/edit

3) Making the Website Public, see:

https://docs.google.com/document/d/14pSTju3hsBXAP212A6CXzUBmlk7hrJF00w7K50vZieQ/ edit\#heading $=$ h.df3gzdpv6u2v

4) Editing a Page, see:

https://docs.google.com/document/d/1t8_466yU77bxtLu5bTney2eCyQxV16uGy1Su5N11GKc/ed it?usp=sharing 


\section{5) Plugin: Embedding PDF Files}

\section{https://docs.google.com/document/d/1-2NYywC4ODiwIHn4kAjmxJv6oiEMl pEWwAEC-}

$\underline{\text { JXgoY/edit?usp=sharing }}$

For more information, you will find useful information to help you through the process in https://www.odu.edu/success/programs/eportfolios/tutorials

The Student Success Center at ODU offers help to students on this. It does not matter if you are on-campus or off-campus, the will make arrangements to help you. You can schedule an appointment to meet with an $\mathrm{eP}$ assistant at the Center. To schedule the appointment go to their website: https://www.odu.edu/success/academic/coaching or email them to academiccoaching@odu.edu. I was told that you might also drop-in and get assistance from any available eP assistant.

\section{ePORTFOLIO REFLECTIONS}

There are two activities where you have to reflect upon the tests you have been collecting in the ePortfolio and a final ePortfolio reflective Letter.

\section{Test reflections}

For every test you archived in your ePortfolio Google drive, you should have a reflection that briefly discusses:

1) How and why the test demonstrates your work toward one, or more, of the course learning objectives. Be specific on the course objectives you decide to mention.

2) A comparison of your test against the available solutions (soon after the test submission deadline, the solutions to the test will be available) and statement of the mistakes you made and what you will do next time to avoid making same mistakes. Please point out exactly where you made the mistake, say why you made the mistake, and how you should have done it. If you were taking this test again, what advice would you give yourself to ensure that you had a successful test?

3) A grade based on the writing rubric provided in the test and the correctness of your solution.

4) A discussion in which you will answer the following questions:

a. What have you learned?

b. Where you think engineers use those concepts (provide specific examples)?

c. Where do you think you will be using everything you learned?

d. Do you think what you learn is important for your professional career?

e. How, when, where and why you might use this information or skill in the future? 
f. Have you been able to apply concepts you have learned in the course to what you do at work or in other courses?

g. What areas did you feel you were most successful, or improved the most?

h. How do you see this course's content intersecting with your field or career?

In the reflection, you should describe the test using facts and feelings providing relevant details. You should identify strengths and weakness of the test and connect the test with experience. Finally, you should also clearly explain the quality of the artifact and give insight and state reason for judgment.

\section{Final ePortfolio Reflective Letter}

In this assignment, you will look back on your experiences and work within the course, discussing what you have learned and how. Your Reflective Cover Letter is a source-based writing; use hyperlinks to directly link to the artifact/evidence from within your cover letter. Also consider addressing a spectrum of classroom activities as evidence of your learning, such as: in-class writing, class discussion, emails, homework, tests, final project, presentations, and editing.

\section{You are going to write to address the following:}

1. Persuade, both your instructor and the institution, that your work meets the objectives for this course. Discuss your learning experiences in this course, including any details that are unique to your own learning process, especially as represented by the contents of your portfolio. The course objectives are as follows:

After completing this course, the student should be able to:

- Describe the nature of fluids and define different fluid properties such as viscosity and pressure;

- Compute pressure and the forces (magnitude, location, and direction) associate with it in a stagnant fluid;

- Discuss what buoyancy is and determine object stability while floating or submerged in a fluid;

- Explain the fluid dynamics in pipes and fittings;

- Apply the principles of conservation of energy (Bernoulli's equation) and mass to fluid flow systems;

- Compute friction losses in pipes for a variety of configurations (series, parallel, network, etc.);

- Identify and solve for different very specific industrial problems, such as, open-channel flow, cavitation, water hammer, drag, lift, forces in pipes, and learn about different instruments to measure fluid flow quantities (such as, pressure, fluid velocity, flow velocity, etc.);

- Explain how fluid-machinery work (focused on pumps);

- Compute and select the appropriate pump for different pipe system configurations. 
2. Answer the following questions, using links or excerpts (visual, audio, or written) from your ePortfolio to illustrate your answers:

1) Where is your learning demonstrated in the course?

2) What areas did you feel you were most successful, or improved the most?

3) How do you see this course's content intersecting with your field or career?

4) Have you been able to apply concepts you have learned in the course to what you do at work or in other courses?

5) How, when, where and why you might use this information or skill in the future?

6) Do you think what you learn is important for your professional career?

7) Where do you think you will be using everything you learned?

8) If you were starting this class again, what advice would you give yourself to ensure that you had a successful semester?

You will put this Final ePortfolio Reflective Letter in the HOME page of your personalized website.

\section{DUE DATES, ACTIVITIES AND GRADING:}

\begin{tabular}{|c|c|c|}
\hline Day & Activities & Additional Points \\
\hline $\mathrm{T}$ \\
$02 / 13$ & $\begin{array}{c}1^{\text {st }} \text { test reflection, Google } \\
\text { drive and web site set up, and } \\
\text { eP update (upload artifacts, } \\
\text { i.e, tests, HWs) }\end{array}$ & 4 points towards $1^{\text {st }}$ test \\
\hline $\mathrm{T}$ & $\begin{array}{c}2^{\text {nd }} \text { test reflection, and eP } \\
\text { update (upload artifacts, i.e, } \\
\text { tests, HWs) }\end{array}$ & 4 points towards $2^{\text {nd }}$ test \\
\hline $\mathrm{R}$ & $\begin{array}{c}3^{\text {rd }} \text { test reflection, and eP } \\
\text { update (upload artifacts, i.e, } \\
\text { tests, HWs) }\end{array}$ & 4 points towards $3^{\text {rd }}$ test \\
\hline $\begin{array}{c}\text { Sunday } \\
04 / 29\end{array}$ & $\begin{array}{c}\text { eP Reflective letter } \& \\
\text { final eP showcase }\end{array}$ & 3 points towards final grade \\
& & \\
\hline
\end{tabular}

On the due date, you will send me a link that will take me to your website showing the embedded test and the test reflection (they should be archived in the Google drive). For the last activity, you will send me the link to your final web page with your eP showcase and your final eP reflective letter. 